\title{
A Blurring of Roles: Use of Force in UN Peacekeeping
}

\section{Uma Indefinição de Papeis: O Uso da Força na Manutenção da Paz da ONU}

\author{
Maria do Céu Pinto Arena, University of Minho
}

\begin{abstract}
There is a sober paradox involved in the use of oxymoron "peace operations", as these operations, traditionally anchored on the bedrock principles of UN peacekeeping - consent of the parties, impartiality, and non-use of force except in self-defence -, are being increasingly transformed into enforcement operations. Twenty-seven years after the end of the Cold War and the rebirth of the United Nations' (UN) security role, peacekeeping operations are increasingly losing ground to an emerging pattern of more aggressive, offensive operations. They have an essentially hybrid nature, involving elements of both peacekeeping and enforcement. Although many see them as alternative, non-reconcilable techniques, politicians and practitioners do not see a sharp dividing line separating non-coercive and enforcement tasks, permitting an easy transition from one to the other.
\end{abstract}

Keywords_UN Peacekeeping Operations (PKO), Use of Force, Enforcement, Hybrid Operations, Asymmetric Environments.

Resumo-Existe um paradoxo relacionado com o uso do oxímoro "operações de paz", uma vez que estas operações, ancoradas tradicionalmente nos princípios fundamentais da manutenção da paz da ONU - consentimento das partes, imparcialidade e não uso da força, exceto em autodefesa -, estão a ser cada vez mais transformadas em operações de fiscalização. Vinte e sete anos após o fim da Guerra Fria e do renascimento do papel de segurança das Nações Unidas (ONU), as operações de manutenção da paz estão cada vez mais a perder terreno para um padrão emergente de operações ofensivas mais agressivas. Elas têm uma natureza essencialmente híbrida, envolvendo elementos tanto de manutenção da paz quanto de "enfocement". Embora muitos os vejam como técnicas alternativas e não conciliáveis, os políticos e os profissionais não vêem uma linha divisória nítida que separa as tarefas não-coercitivas e de execução, permitindo uma transição fácil de uma para outra.

Palavras-Chave-Operações de Paz da ONU (PKO), Uso de Força, Enforcement, Operações Híbridas, Ambientes Assimétricos.

Submitted-20-07-2017. Accepted-19-12-2017.

\section{From peace-keeping to peace- enforcement}

- Maria do Céu Pinto Arena, Research Center in Political Science, Associate Professor with Aggregation of the Department of International Relations and Public Administration of University of Minho.

E-mail:mceupinto@gmail.com

DOI:http://dx.doi.org/10.21814/perspectivas.102
\Tith the end of the Cold War, the UN began to authorise new peacekeeping missions explicitly under Chapter VII, providing a prominent place to the use of force or other coercive measures. Since the end of the Cold War, the Security Council (UNSC) has declared more instances for the use of force as legitimate, than during the first four decades of its existence. Since the 1990s, resolutions instituting new operations, not only fall under Chapter VII, as they further 
determine the existence of situations of 'threats to peace and international security ${ }^{1}$. Since the turn of the century, corresponding to the release of the 'Brahimi Report', UN resolutions invoke Chapter VII, and detail specific situations where peacekeepers are allowed to 'use all necessary means' to carry out their mandate (Sloan 2014, 692). Thus, peacekeeping is no longer a non-offensive undertaking: it has evolved into a proactive, offensive activity (Sloan 2014, 691). 'Robust peacekeeping' was defined as 'a political and operational strategy to signal the intention of a UN mission to implement its mandate and to deter threats to an existing peace process in the face of resistance from spoilers' (UN 2009, 21) ${ }^{2}$.

As a rule, the use of force, authorized by the UNSC, is intended to enhance the implementation of the mandate of peacekeeping operations, or the implementation of agreements between warring parties. Initially, the use of force was only authorized for self-defence purposes ${ }^{3}$, that is, defence of the soldier by means of its weapons. The concept of self-defence expanded, starting to include resistance to attempts by force to prevent peacekeepers from fulfilling their mandated duties (Sloan 2014, 684). After the establishment of UNEF II in 1973, the self-defence rule was expanded to accommodate the need for 'defence of the mission' (Hunt 2016, 3).

However, experience has highlighted the need to further extend this understanding to allow peacekeepers to use force in order to: (1) prohibit attempts to disarm them, (2) defend their positions, vehicles, and equipment against armed attacks or attempts to capture them, and, (3) support other UN contingents (IPA 1984, 57). This concept was later broadened to allow UN peacekeepers to protect civilian agencies and other UN staff. Since 1999, the protection of civilians is increasingly at the centre of the mission: "this increased focus on humanitarian objectives re-

1. See UNSC Resolution 2304 of August 122016 on the UN Mission in South Sudan (UNMISS), authorizing an expanded peacekeeping force to bolster civilian protection in its mandate.

2. Defined as 'those who lie outside and seek to undermine the peace process, including through violent means' (Report 2015, paragraph 108).

3. Defined as 'those who lie outside and seek to undermine the peace process, including through violent means' (Report 2015, paragraph 108). flects a welcome shift in normative climate after the Cold War, its central place in peacekeeping mandates...' (Berdal and Ucko 2015, 11). Current authorizations tend to specify that the physical protection of civilians in UN peacekeeping be limited to civilians "under imminent threat of physical violence', and only where such protection can be accomplished by the mission 'within its capabilities' and 'within its areas of deployment' (Sloan 2014, 694) ${ }^{4}$. It also states that the 'protection of civilians is the primary responsibility of the host country', which means that the UN's role is to 'support the efforts of the host authorities in protection of civilians from violence' (UNSC Resolution 2086 2013, para. 8.h).

A latter trend was that the UNSC has authorized member states or coalitions of states to use force by delegation, and on its behalf. In fact, Article 53 says that the UNSC may resort to regional arrangements or agencies for enforcement action, under its authority. Thus, if they engage in 'robust peacekeeping' and 'peace enforcement' they are subject to UN Security Council approval and oversight (Hettne and Söderbaum 2006, 229). United Nations post-Cold War interventions (Cambodia, Somalia, Bosnia-Herzegovina, and Rwanda) occurred in volatile, high-risk, uncertain environments, and in civil wars with multiform contours. As Mackinlay and Chopra point out, in these operations it is essential that the contours of the use of force be defined without ambiguity. It is necessary '... that clear political decisions precede and sustain a mandate ... but in the execution of tasks, the importance of military effectiveness grows as the intensity of the operation increases, until, at the threshold of collective enforcement, it becomes the main key to success' (Mackinlay and Chopra 1993). These operations have been referred to

4. S. Resolution 1769 of July 31 2007, on the joint African Union/United Nations Hybrid operation in Darfur (UNAMID): Acting under Chapter VII of the Charter, the UNSC 'decides that UNAMID is authorized to take the necessary action, in the areas of deployment of its forces and as it deems within its capabilities in order to: protect its personnel, facilities, installations and equipment, and to ensure the security and freedom of movement of its own personnel and humanitarian workers; support early and effective implementation of the Darfur Peace Agreement, prevent the disruption of its implementation and armed attacks, and protect civilians, without prejudice to the responsibility of the Government of Sudan' (UNSC Resolution 1769 2007, para. 15). 
in traditional slang as 'middle ground' or 'grey area operations', as they are halfway between traditional peacekeeping and peace-enforcement. Brian Urquhart, one of the architects of UN peacekeeping, has admitted the need for an intermediate option between the peacekeeping/peaceenforcement binary: 'a third category of international military operation is needed, somewhere between peacekeeping and large-scale enforcement. It would be intended to put an end to random violence, and to provide a reasonable degree of peace and order so that humanitarian relief work could go forward and a conciliation process could commence. The forces involved would be relatively small, representatively international, and would not have military objectives as such. But, unlike [traditional] peacekeeping forces, such troops would be required to take, initially at least, certain combat risks in bringing violence under control. They would essentially be armed police actions' (Urquhart 1991, 9). The peace operations of the 1990s glaringly displayed the shortcomings of traditional peacekeeping principles, in operations characterized by limited consent: they were labelled 'complex operations' because they may require the partial use of force to ensure the execution of the mandate. The case of the UN operation in Somalia clearly shows how local forces may not agree with the UN presence or with a peace plan, even because the various rebel factions may not be under the control of any of the main parties to the conflict, may lack a formal internal structure and coherent leadership, and, thus be viable interlocutors. In these cases, the UN has no line of communication with the 'spoilers' (should they be identifiable at all!), or there is a common understanding of a peace agreement and of the mandate of the blue helmets. In cases of anarchy, the UN may abandon any pretence of consent, and establish a presence in the country through an enforcement action under Chapter VII, as happened with the American mission in Somalia in December 1992 (UNITAF, Unified Task Force on Somalia). More recently, the United Nations Operation in Côte d'Ivoire (UNOCI) refused to comply with President Laurent Gbagbo's request to leave the country, eventually being dragged into a military showdown against Gbagbo's forces, including targeting the presiden- tial residence (Piccolino and Karlsrud 2011, 458). The UN Mission to Chad and the Central African Republic, MINURCAT, was requested to pull out of Chad by the end of 2010, barely after less than three years on the ground. Only reluctantly did the government accept the mission, and then succeeded in terminating it in an expedite manner, after undermining its role and rendering it unable to comply with its major engagement - supporting the protection of civilians within a larger peacebuilding agenda (Piccolino and Karlsrud 2011, 459-461). The 'withering consent' poses a 'difficult dilemma to the UN, balancing between keeping peacekeeping missions on the ground with limited or no consent, or leaving and risking breaking its implicit engagements with the civilian population.' (Piccolino and Karlsrud 2011, 447).

Coming back to the use of force in 'defence of the mission' this is an area is which there is a [middle] muddle ground $)^{5}$, because it has generated confusion and uncertainty as regards the right sense of interpretation, especially in terms of force commanders. As is widely known, the UNSC tends to draft the mandate of its missions in the broadest possible terms, and to be the least concrete possible regarding crucial details, potentially compromising the proper functioning of the mission: as, what to do if the mission cannot perform tasks that have been committed to it; what if the parties do not cooperate or deliberately offer resistance. Mandates are often too general, to be able to anticipate and resolve the practical challenges missions face in assisting peace and security tasks.

Given the usual aloofness of the UNSC, the responsibility to interpret the sense of "defence of the mission" is devolved upon the SecretaryGeneral/Secretariat. The interpretation of what is the 'defence of the mission' obviously depends on the nature and context of the mission. If it is essentially a humanitarian mission, then the use of force can be allowed so that peacekeepers have free access to critical areas. If the mission

5. It is a homophonic pun. It alludes to the fact that 'the middle ground in contemporary UN peacekeeping is so confusing that it may be more aptly described as the "(middle) muddle ground", not least because UN forces deployed in such operations are perceived to be muddling through in the execution of a variety of incoherent mandates, without the reassurance of a clear-cut doctrinal foundation for operations' (Malan 1996, 2). 
requires disarming and demobilizing combatants, using force may be more problematic, since it can trigger a spiral of confrontation. In this regard, it is important to note the Security Council's Resolution 1674 of 2006 on the protection of civilians in armed conflicts, a landmark document on a particular thematic area of concern to peace operations. It says that attacks against civilians and 'the deliberate targeting of civilians and other protected persons, and the commission of systematic, flagrant and widespread violations of international humanitarian and human rights law in situations of armed conflict, may constitute a threat to international peace and security' (para. 26). The Resolution reaffirms in this regard 'its readiness to consider such situations and, where necessary, to adopt appropriate steps...' (para. 26). The Resolution also specifies that: 1. mandates of UN peacekeeping, political and peacebuilding missions include clear guidelines as to what missions can and should do to protect civilians; 2 . the use of available capacity and resources must be prioritized to enable the protection of civilians, and 3. protection mandates must be effectively implemented (para. 16). The Report on the Rwanda genocide also blamed the UNSC for lack of political will to increase the intervention force in Rwanda in order to stop the massacres. In face of the genocide, the Report concludes that the UN has 'an obligation to act which transcended traditional principles of peacekeeping' (Report 1999, 50).

The doctrine of 'muscular peacekeeping' has been gaining acceptance within the UN Secretariat. That is what some authors have labelled a 'robust turn' (Hunt 2017, 110 and ff.). The experience of peacekeeping operations in the 1990s has helped overcome the taboo on the use of force (Annan 1993) ${ }^{6}$ However, the use of force within the framework of peacekeeping missions is a controversial matter, and the on-going discussions on this subject are not clarifying. When in 1992, Boutros-Ghali, in the Agenda for Peace, advocated the use of 'enforcement-units', that is, peacekeeping forces mandated to use force, he

6. In 1993, Annan stated: 'the principles and practices which had evolved in the Cold War period suddenly seemed needlessly self-limiting. Within and outside the UN, there is now increasing support for peacekeeping with teeth' (Annan 1993). strongly challenged the organization to use such forces in special circumstances only, such as failure to make belligerents comply with cease-fire agreements.

For those cases, he recommended 'that the Council consider the utilization of peaceenforcement units in clearly defined circumstances and with their terms of reference specified in advance. Such units from Member States would be available on call and would consist of troops that have volunteered for such service. They would have to be more heavily armed than peacekeeping forces and would need to undergo extensive preparatory training within their national forces' (UN 1992, para. 44). This is a type of intervention which, as the Secretary-General (SG) acknowledged, '... on occasion exceed the mission of peace-keeping forces and the expectations of peace-keeping force contributors' (UN 1992, para. 44). According to Boutros-Ghali, it would be up to the SC to decide, when and in what terms to exceed the limits of traditional peacekeeping. However, this bold proposition left a series of crucial questions unanswered: to what extent may these tasks exceed the boundaries of peacekeeping, stricto sensu? Which are the consequences, as far as peacekeeping philosophy, of the incorporation of coercive principles in operations that are peaceful, neutral, and impartial? That assumption rested on the premise that peace-enforcement was a more advanced stage of peacekeeping, and not a deviation or outright contradiction to it. Authors such as Adam Roberts challenge the interpretation that views peace-enforcement as an extension of peacekeeping: 'It must be doubtful whether it is right to hi-jack the respected term "peacekeeping" and apply it to actions which are not based on the full consent of all the parties, and which involve extensive use of force' (Roberts 1994, 110).

In the Supplement to an Agenda for Peace, and following the Somalia disaster, Boutros-Ghali abandoned the concept of peace-enforcement units to return to the traditional terms of peacekeeping, and of enforcement in its narrower understanding. In 1995, the UNSG stated that peacekeeping operations require the consent of the belligerents, and that the use of force is not within the nature of peacekeeping: it 'is necessary to 
resist the temptation to use military power', he said, even when it could 'speed up the resolution of the conflict' (UN 1995, para. 36). The rationale for that new understanding was that 'the logic of peace-keeping flows from political and military premises that are quite distinct from those of enforcement; and the dynamics of the latter are incompatible with the political process that peace-keeping is intended to facilitate. To blur the distinction between the two can undermine the viability of peacekeeping operations and endanger its personnel' (UN 1995, para. 35). The proposal of 'muscular peacekeeping' (peace enforcement units), like other proposals contained in the Agenda for Peace, had an exploratory nature, in an attempt to articulate new paths to strengthening and making more efficient the United $\mathrm{Na}$ tions capacity for preventive diplomacy, peacemaking, and peace-keeping. They were trial balloons, of an ambitious and active SG that seized on the historic opportunity opened up by the end of the Cold War, as well as the availability of the permanent members of the UNSC, who, in January 31 1992, in a UNSC meeting of Heads of State and Government, encouraged the UNSG to provide recommendations to make of the UN an effective organization in resolving conflicts. However, all these initiatives were ultimately bound to be accepted by the UNSC permanent members. In 1995, the atmosphere of enthusiasm that had marked the launch of the Agenda for Peace had been fatally marred by the United Nations Operation in Somalia II (UNOSOM II) disaster in the streets of Mogadishu. The UN stressed, however, that peacekeeping forces should not be mixed up or confused with peace-enforcement forces; that peacekeeping operations should not be of a coercive nature (Jakobsen 2000, 46). Enforcement is presented as an activity that by its very nature requires separate and distinct forces from peacekeeping.

In UN Peacekeeping in Trouble: Lessons Learned from the Former Yugoslavia, Wolfgang Biermann and Martin Vadset bring together the contributions of some of the key players in resolving the war in the former Yugoslavia. Among them are the United Nations Protection Force (UNPROFOR) commanders Gen. Bertrand de Lapresle and Gen. Michael Rose. The conclu- sions of these protagonists are remarkable by the consensus that they express on the reluctance to using force within the scope of peacekeeping. They underline, on the one hand, the natural incompatibility between peacekeeping and peaceenforcement. While on the other hand, they assert that '... classic peacekeeping principles of consent, impartiality, and use of force in self-defence... remained fundamental to the success of peacekeeping operations in civil war-type situations such as that in FY' (Biermann and Vadset 1998, 57). Gen. Michael Rose says it is crucial that "warfighting goals are never pursued by peacekeeping forces (Rose 1998, 158) ${ }^{7}$.

The use of force in Yugoslavia was assessed in an extremely negative manner by those protagonists. First of all, because, from the outset, UN forces had not been prepared, trained, and equipped for a coercive operation. Secondly, because the decision to use force was an improvised reaction to circumstances, and therefore lacked the means for military planning and a fair political evaluation of its appropriateness as an instrument for peacekeeping. Thirdly, because the use of force was often a response to pressure from international public opinion. Fourth, because the international community was deeply divided over the usefulness and relevance of using force. In general, the mandate to use force plunged UNPROFOR into a "vicious circle: more enforcement - less support - more chaos in UN operations' (Biermann and Vadset 1998, 25).

In the Agenda for Peace, Boutros-Ghali minimized the issue of consent by defining peacekeeping as a 'United Nations presence on the ground, hitherto with the consent of the parties concerned ...' (UN 1992, para. 20). Some commentators interpreted this bold stance of the SG as a reconceptualization of peacekeeping that raised serious concerns, and an increasing willingness to take risks. Some experts, such as Thomas Weiss, expressed discomfort and concern about the lack of practicality of those proposals (Weiss 1995, 176). The use of the expression 'hitherto' was intentional, since the launching of the United Nations Mission Preventive Deployment Force (UNPREDEP) to Macedonia was done without the consent of the

7. Author's italics. 
Serbs.

Perhaps, as a consequence of the operations in Bosnia-Herzegovina and Somalia, Boutros-Ghali restored the UN original, non-coercive formulation. In 1995, in his Supplement to the Agenda for Peace - although showing great circumspection in the choice of words -, he seemed to abandon the idea of peacekeeping action where the consent of the belligerents was not assured and where force might be employed. The UNSG stated that successful peacekeeping was one where $\mathrm{PKO}$ 'principles' were respected and 'in most of the less successful operations one or other of them was not' (Supplement 1995, para. 33). Boutros-Ghali thus returned to the traditional dichotomy peacekeeping/enforcement operations. As Biermann and Vadset would say, this attitude '... can be interpreted as a return to principles, less ambitious and more realistic UN operations'. This cautious attitude did not prevent the UN from engaging in difficult-to-frame contexts where peacekeeping came to be combined with peace-enforcement and the absence of consent.

The use of force in peacekeeping missions is a controversial matter and the on-going debates on this matter are not even enlightening. Sir Gen. Michael Rose, former commander of UNPROFOR, coined the phrase 'Mogadishu line' - which later became popular in discussions in this area - to convey the idea of the risks undertaken by crossing the border that separates peacekeeping from peace-enforcement. Gen. Rose says that the level of force that exceeds the requirements of peacekeeping is like '...crossing the border - the line of Mogadishu - that separates combatants from non-combatants' (Rose 1998, 159). Gen. Rose states that it is obvious that when a military force is in the service of a humanitarian peacekeeping mission, it is forbidden, by its very nature and rules of engagement, to act as a combatant (Rose 1998, 157). The UNPROFOR commander says that his experience is a demonstration that military action in the context of peace operations jeopardizes the lives of blue helmets, and undermines the humanitarian part of the mission (Rose 1998, 159). Gen. Rose gives the example of Bosnia and Herzegovina, where aid to Muslims living in the enclaves was conducted through territories controlled by Serbs. The Bosnian Serbs had a policy of preventing the creation of deposits of essential goods in order to maintain a constant pressure on the populations. At the end of the day, it were these communities that paid the highest price when NATO or UNPROFOR used force to counter attacks or provocations: they were the most directly affected since they were dependent on UN humanitarian aid. Gen. Rose also says that the use of force in Bosnia-Herzegovina put at risk blue helmets scattered on the ground and in numerical inferiority. The Serbs were well aware of the reduced military capacity of UN forces, and of the vulnerabilities of peacekeepers, which penalized the latter. In April 1994, after a series of NATO bombings caused by the Serb attacks on Goradze, they took 155 blue helmets as hostages (Rose 1998, 159). However, Rose himself acknowledges that if the peace mission involves tasks, such as 'deliver aid, maintain the regime of a total exclusion zone or deter attacks against Safe Areas then it will have to adopt a very forceful approach to peacekeeping indeed. To be credible, a peacekeeping mission must be in a position to escalate, moving if necessary beyond the traditional Chapter VI peacekeeping to peaceenforcement' (Rose 1998, 157). He further says that 'a commander on the ground must nevertheless be given the discretion to use force as and when he sees fit... It is therefore essential that the Rules of Engagement under which he operates must be flexible enough to give him leeway to act. Thus, if, when the mission is first deployed there exists the possibility that force will be required, then the mandate, and resources, will have to clearly reflect this' (Rose 1998, 158). Eventually, he takes the view that '... the need to maintain consent and impartiality on one hand, and the need to use force on the other, must be reconciled in the minds of the international community if peacekeeping is going to continue to be a viable option of international conflict resolution' (Rose 1998, 157).

In the report on the Srebrenica tragedy of July 1995, Kofi Annan made an eloquent call for a more robust response to future humanitarian tragedies. He stated: 'The cardinal lesson of Srebrenica is that a deliberate and systematic attempt to terrorise, expel or murder an entire people must be met decisively with all necessary means, and with 
the political will to carry the policy through to its logical conclusion' (UNGA 1999, para. 501). In Bosnia-Herzegovina and Kosovo, it would have been necessary to use force to put an end to organized campaigns to eliminate and expel the population. The blue helmets in Srebrenica (the Dutch battalion Dutchbat-3) numbered around 600 personnel. About half had only light armament and acted under the peacekeeping rules of engagement. They did not have tanks, and the approach towards the Serbs was only to fire warning shots. The 2000 Serbian forces, on the other hand, were equipped with armour and artillery. At the beginning of the offensive against the so-called 'protected areas', the Dutch commander asked for NATO's air support against the approaching Bosnian-Serb army led by General Ratko Mládic. His request was rejected by the SecretaryGeneral's Special Representative Yasushi Akashi, and by the military commander of the UN forces in Bosnia and Herzegovina, Gen. Bernard Janvier. On July 11, Janvier and Akashi approved the attack, but limited to the use of battle tanks and Serbian artillery - conditions that made it difficult for NATO pilots to act. On learning of this decision, the Dutch defence minister called for the suspension of the attacks, claiming that the Dutch blue helmets could be hit, given their proximity to the Serbs on the ground.

In these conditions, the Dutch troops were vastly outgunned and outnumbered, and had no choice but to give in without resistance: some surrendered, others were captured or withdrawn from their posts. The Dutch helped the Serbs evacuate the population of the city, including sorting the population, that is, separating men (aged between approximately 16 and 65) from women, children, and elderly. More than 8,000 Bosnian Muslims were subsequently killed. The report concludes that the use of air strikes in support of blue helmets was 'clearly warranted', since Serbian artillery attacks had begun five days earlier (UNGA 1999, para. 480).

\section{Doctrinal Developments in the Af- termath of the Brahimi Report}

Kofi Annan, the new Secretary General after the 1990s Rwanda and Srebrenica tragedies, took a more open position on the role of the UN in peace operations. In March 2000, Annan convened the 'Panel on United Nations Peacekeeping Operations', led by Algerian diplomat Lakhdar Brahimi. In the history of the UN, the Brahimi Report is the work that presents the most profound reflection on the issue of peacekeeping, advancing with new critical concepts. The conclusions of the Brahimi Report are the outcome of the evolution of peacekeeping in the 1990s, particularly rapid and fruitful in terms of new developments and lessons learned. The report also stems from Annan's personal experience in the management of post-Cold War peace operations. Annan publicly acknowledged the flaws that undermined the organization's credibility, in particular the Secretariat's remissness regarding the building up of the Rwandan conflict. SG Annan said that the UN needed to develop a 'new paradigm' for peace operations, in particular to focus on 'inducing consent' measures. He also advocated the need for the UN to equip itself with the skills to swiftly deploy personnel into peacekeeping scenarios, properly resourced and equipped, as well as the means of intelligence gathering (Annan 1998, 172). Annan questioned the sacred principle of consent of the parties, saying that in the context of states in anarchy, this requirement could be 'neither right nor wrong', but 'quite simply, irrelevant' (Annan 1998, 172). Ultimately, consent is dependent on the will of the parties. It is not a decision that the parties to a conflict take in abstract, but depends on the alternatives at hand and the calculation of opportunity: 'If consent carries with it certain rewards and the failure to consent carries certain costs, this obviously affects the decision as to whether or not consent will be granted' (Annan 1998, 172-3). Thus, a mission must be prepared to offer a panoply of costs and rewards. Annan used the term 'induced consent' and 'coercive consent', the first consisting of rewards to gain the goodwill of the population and of the erstwhile antagonists to further the reconciliation process, and the second intimidating the recalcitrant and warlords into 'acquiescence' (Annan 1998, 174$5)$. The purpose of induction operations is to: '... restore civil society where it has broken down by two methods: (1) the use of positive incentives (rewards) to induce, in the first instance, consent 
and cooperation with the peace operations, and, beyond that, reconciliation, and, (2) the threat of coercion to gain the consent and cooperation, however grudging, of those who are unresponsive to positive incentives' (Annan 1998, 173). According to Annan, it is essential to obtain, from the outset, and then continuously cultivate, the acquiescence of the majority of the population to the UN presence. A UN mission should try to create positive incentives for 'winning the hearts and minds' of the population. In any case, the use of coercion/force, albeit in fundamental contradiction with the spirit of peacekeeping, is subordinated to a higher-level logic. It always has a constructive purpose: to persuade spoilers to cooperate in a plan for the reconstruction and pacification of a society. The 'Lessons Learned Unit', of the Department of Peacekeeping Operations, has come to accept the concept of acting as a well-armed and effective force. The Brahimi Report maintains the term peacekeeping, but uses the terms 'complex' or 'robust' operations to refer, euphemistically, to peace enforcement (Report of the Panel 2000, viii, xi). The Report thus calls into question some of the assumptions of classical peacekeeping. The Report is an apologist of 'muscled forces', '... in contrast to the symbolic and non-threatening presence that characterizes traditional peacekeeping' (Report of the Panel 2000, para. 51). The Brahimi Report is quite peremptory when it argues that once deployed, UN military units should be able to defend themselves, the various components of the mission, and the mandate. Rules of engagement should be 'robust', against those who renege on their commitments to a peace accord or that otherwise seek to undermine it by violence, 'to cede the initiative to their attackers' (Brahimi, para. 49). Mandates should also specify the authority of the operation to use force. UN forces should be larger and better equipped to have a credible deterrent potential, which obviously contrasts with the nonthreatening posture that characterizes traditional peacekeeping. In line with the logic laid out above, 'defence of the mandate' has been implemented mainly in the sense of protecting civilians, but also extends 'to assuming a deterrent posture to proactively dissuade 'spoilers', ensure the freedom of movement of peacekeepers, and other terms of the Status of Forces Agreement' (Hunt 2016, 4).

The 2004 Report produced by the High-level Panel on Threats, Challenges and Change, $A$ More Secure World: Our Shared Responsibility, also deals with the issue of the use of force by the UN. It frames it as a response to threats foreseen under Chapter VII ${ }^{8}$. The Report says that it became the current practice of the UNSC to provide peacekeeping missions with a mandate under Chapter VII.

The document justifies this '...on the basis that even the most benign environment can turn sour - when spoilers emerge to undermine a peace agreement and put civilians at risk - and that it is desirable for there to be complete certainty about the mission's capacity to respond with force, if necessary' (UN 2004, para. 213). The Report is contradictory on this issue: it recommends robust missions if they are to face hostile opposition, but admits those contexts 'are not appropriate for consent-based peacekeeping; rather, they must be met with concerted action' (UN 2004, para. 222). In peacebuilding missions, where post-conflict peace-building tasks are often undermined by spoilers and by the different factions in conflict, 'contingency plans for responding to hostile opposition should be an integral part of the mission design; missions that do not have the troop strength to resist aggression will invite it' (UN 2004, para. 222). The UN's 2008 capstone doctrine on peacekeeping was an attempt to codify the basic principles and concepts underpinning the conduct of contemporary United Nations in light of the major lessons of United $\mathrm{Na}-$ tions peacekeeping experience (UNDPKO 2008). It argues that 'while robust peacekeeping involves the use of force at the tactical level, with the consent of the host authorities and/or the main parties to the conflict, peace enforcement may involve the use of force at the strategic level' - although the report acknowledges that this

8. Regarding the use of force under Chapter VII in response to 'any threat to peace, breach of peace or act of aggression', the report distinguishes between external threats (actual or potential, to other States or people outside its borders), and internal threats (to a State's own people), and the consequent responsibility of States to protect their populations. In all cases, in order to be legitimate, the use of force must meet the following criteria: seriousness of threat; proper purpose; last resort; proportional means, and balance of consequences (UN 2004, para. 56). 
line 'may appear blurred' (UNDPKO 2008, 19). The document distinguishes the two instances, underlining that there are important differences. Robust peacekeeping involves the use of force at the tactical level, meaning with the consent of the host authorities and/or the main parties to the conflict. Peace enforcement involves the use of force at the strategic or international level, which is normally prohibited for member States, unless authorized by the Security Council (UNDPKO 2008, 19). ${ }^{9}$

The High-Level Independent Panel on Peace Operations (HIPPO) convened in 2014 by Ban kiMoon conducted a comprehensive assessment of the state of UN peace operations, and the emerging trends regarding the future. The Panel cautioned against the tendency to resort to enforcement tasks in the gambit of a UN peacekeeping operation. It specified a number of important prerequisites to be taken into consideration in availing such a possibility: 1. 'any such mandate task should be a time-limited, exceptional measure'; 2 . it should be 'conducted in support of a clear and achievable political end state', and 3. 'in full respect of international humanitarian law' (UNGA and UNSC 2015, para. 119). As stated in previous documents, the Report underlines such operations may make the UN forces, and the mission as a whole, a party to the conflict. It also points to the negative downside for the humanitarian, and other consequences that invariably flow from the sustained use of force. The Panel supports the view of humanitarian interlocutors on the need to maintain a clear distinction between peacekeeping operations with enforcement mandates, and humanitarian actors and objectives.

\section{Emerging Trends}

The challenge posed by the question is increasingly relevant, bearing in mind that the UN has been increasingly called upon to intervene and mediate conflicts. It is engaged in 39 missions

9. Similarly, in 2012 the UNSG's report on peacekeeping reform argued that contrary to enforcement activity, 'respect for the basic principles of peacekeeping, such as the consent of the parties, impartiality and the non-use of force except in self-defence and in the defence of a mandate authorized by the Security Council' (GA 2012, 25). across the globe, with 128,000 civilian and uniformed personnel. In the context of these demands, the UN is required to juggle several shortcomings in responding to new emergencies: dwindling resources, the diminishing willingness of member states to contribute, and ever more insecure environments and intractable conflicts. In the first two decades of this century we have noticed a number of trends regarding peace operations with an enforcement bend. One of the most significant is the attitude of the developed, Western contributors. Regarding the use of force, states have actually shown a dual attitude. On the one hand, they insist that the mandate of UN operations should provide for the use of force in self-defence, so as to enable troops to defend themselves. On the other hand, they are reluctant to allow peacekeeping operations to use that capacity and engage in enforcement activities (Tardy 2007, 60). The reluctance to authorize enforcement missions lies in the fact that, because of their more forceful nature and the potential for confronting 'spoilers', there is greater likelihood of there being casualties. Attacks on UN troops and police have negatively affected the willingness of troop contributing countries to deploy to UN missions (Karlsrud 2015, 49). Furthermore, in the case of more important states, the fear is that the organization may usurp their monopoly on the use of force. In all cases, and, especially since the failures of peace operations in the 1990s, there is a diminishing political will for robust intervention by member states and UNSC members. The most powerful UN states have shifted their resources away from UN operations, which has created resource constraints that hamstrung current UN peacekeeping missions. Western states have contributed personnel to so-called 'hybrid missions', that is, missions that work in step with UN forces or troops from other international organizations. That was the case of Balkan operations, such as the NATOled Stabilisation Force (SFOR) in Bosnia (1996), and the Kosovo Force (KFOR), which supported the UN Mission in Kosovo (UNMIK). In those cases, the Western troop contribution lies outside the command and control structures of the United Nations (Bellamy and Williams 2009, 44). A parallel and related trend is the role played by 
the UN's more powerful member states assisting UN operations facing a threat to the mandate or a sudden deterioration in the security environment. This is what Bellamy and Williams have called 'fire-fighting' operations: deployments to conduct limited enforcement activities alongside on-going UN operations (Bellamy 2009, 48). Western 'fire-fighting' operations include the British military engagement in Sierra Leone in 2000, the French-led Operation Turquoise in support of UNAMIR in Rwanda (1994), the 2003 French-led Interim Emergency Multinational Force (IEMF - Artemis) in the Democratic Republic of the Congo (DRC), and the 2013 French Operation Serval, in which special forces targeted armed groups in Northern Mali (Perito 2015, 8-9; Karlsrud 2015, 47). In recent years, many sub-Saharan conflict zones in particular have witnessed the swift deployment of Western quick-reaction forces within the context of broader UN operations. In those cases, contributions 'tend to be relatively small (consisting, at most, of a few thousand soldiers), deployed for only a short period of time and confined to limited geographical areas' (Bellamy and Williams 2009, 50). This option is more palatable to Western powers, which privilege shorter-term engagements, rather than the drawnout and costly deployments, such as the one in Afghanistan. A second trend, a doctrinal change in UN peacekeeping, is that the use of force is linked to stabilization operations. As has been mentioned above, civilian protection has become a hallmark of the new generation of missions, but it is the stabilization logic that underlies the application of force. What stabilization operations have in common is, that they operate in the midst of ongoing conflicts, and, they work to bolster the authority of civil authorities. Their mandates tasks them to contribute to support the government and to build the host nations' capacity to bolster state authority, which, actually means restoring and maintaining order in a given situation against the moves of identified aggressors. Thus, they are tasked to undertake robust operations against specific spoilers (Hunt 2017, 112). Contrary to the original spirit of peacekeeping, the focus of which is on conflict resolution; in stabilization the objective is limited to conflict management or containment (de Coning 2015). The focus on tack- ling spoilers, which inhibit the extension of state authority, informed the reconfigurement of the mission in the Democratic Republic of the Congo (UN Organization Stabilization Mission in the Democratic Republic of the Congo - MONUSCO) and, more recently, authorized operations in Mali (MINUSMA), and in the Central African Republic (UN Multidimensional Integrated Stabilisation Mission in the Central African Republic - MINUSCA) (Hunt, 112). An example of these new, targeted, offensive operations was the launching in March 2013 of the Intervention Brigade (UN Force Intervention Brigade - FIB), within the existing MONUSCO. The brigade was announced as the first-ever United Nations 'offensive' combat force intended to neutralize and disarm the rebel groups (Hunt 2017, 112-113; Karlsrud 2015, 45). Opponents complained that the FIB endangered other UN military forces in the DRC that operated under a traditional peacekeeping mandate, and which were not prepared for combat. Critics argued that the FIB made the United Nations a party to the conflict, violating the core peacekeeping principles of impartiality and non-use of force. It undermined the legal protection afforded by peacekeepers based on their neutrality. The UN acted in a clearly partial way, by siding with one of the armed groups (albeit the armed forces of an elected government), and by identifying other groups - primarily the rebel military group M23/Congolese Revolutionary Army -, as spoilers to be 'neutralized' militarily. Humanitarian groups voiced concerns that the FIB's combatant status would turn civilian and humanitarian components of the UN into potential targets (Karlsrud $2015,45)$. Another issue that is worth considering in the present context, is the fact that UN operations - as highlighted in the HIPPO Report - are required to operate in environments where there are violent extremist forces and terrorist groups, such as al-Qaeda in the Islamic Maghreb, and Ansar al-Dine in Mali. Seven missions currently deployed (IPI 2016, 2) operate in countries where al-Qaeda and Daesh (the so-called Islamic State) are an incumbent threat to the missions. Interventions in asymmetric environments were foreshadowed by the UN Assistance Mission in Afghanistan (UNAMA), alongside the NATOled security mission, International Security Assis- 
tance Force (ISAF) (Perito 2015, 7). This points to the need to equip soldiers with more sophisticated means, such as using a combination of human and signal intelligence sources such as drones, and including Special Forces to support more conventional forces (Karlsrud 2015, 49). More war-prone UN operations are a result of the counterinsurgency lessons drawn from U.S. and coalition efforts in Afghanistan and Iraq.

\section{Conclusion}

The move towards peace enforcement has been conformed as a trend in UN peace operations ever since the end of the Cold War, and, especially, in the new century. UN PKO have proven to be a flexible and adaptable tool that has evolved over time to respond to evolving challenges. The understanding of the use of force has evolved over time, as well as its degree and level. At times, peacekeeping and peace-enforcement were seen as adjacent points on a continuum, and not as alternative techniques. At present, offensive operations are on the verge of raising the use of force to a strategic/operational level, instead of the more unbiased tactical level to defend the mission and manage spoilers. A more robust posture is the response to the new unstable security environment, punctuated by irregular actors and asymmetric threats. Currently, the UN is deployed to a range of environments where it conducts military counterterrorism operations, as in Afghanistan, Iraq, Libya, Mali, and Somalia. There remains the larger challenge of the ultimate purpose of the use of force, that is, the appropriate level which serves the mission's purposes, without undermining the UN's peacekeeping reputation as a neutral arbiter. There is a predicament of peacekeeping soldiers: to use force, or the failure to use force when action is required, which impact the confidence of the local civilian population and the international community. The dilemma is finding the right balance in applying force, without crippling the constitutive principles of the institution of peacekeeping in general.

\section{References}

[1] Annan, Kofi A. 1998. "Challenges of the New Peacekeeping." In Peacemaking and Peacekeeeping for the New Centur, edited by Olara A. Otunnu e Michael W. Doyle, 169-87. Lanham, MD: Rowman Littlefield Publications.

[2] Annan, Kofi. 1993. "UN Peacekeeping Operations and Cooperation with NATO." NATO Review 47(5).

[3] Bellamy, Alex J. and Paul D. Williams. 2009. "The West and Contemporary Peace Operations." Journal of Peace Research 46(39).

[4] Berdal, Mats and David H. Ucko. 2015. "The Use of Force in UN Peacekeeping Operations." The RUSI Journal 160(1): 6-12.

[5] Biermann, Wolfgang and Martin Vadset. 1998. "Setting the Scene." In UN Peacekeeping in Trouble: Lessons Learned from the Former Yugoslavia, edited by Wolfgang Biermann and Martin Vadset. Aldershot: Ashgate.

[6] GA/SC, 2015. Comprehensive Review of the Whole Question of Peacekeeping Operations in All Their Aspects, A/70/95-S/2015/446, 17 June.

[7] Hettne, Björn and Fredrik Söderbaum. 2006. "The UN and Regional Organizations in Global Security: Competing or Complementary Logics?" Global Governance 12(3): 229.

[8] International Peace Institute. 2016. UN Peace Operations in Violent and Asymmetric Threat Environments, March.

[9] International Peace Academy. 1984. Peacekeeper's Handbook. New York: IPA e Pergamon Press.

[10] Karlsrud, John. 2015. "The UN at War: Examining the Consequences of Peace-Enforcement Mandates for the UN Peacekeeping Operations in the CAR, the DRC and Mali." Third World Quarterly 36(1): 40-54.

[11] Jakobsen, Peter Viggo. 2000. "The Emerging Consensus on Grey Area Peace Operations Doctrine: Will It Last and Enhance Operational Effectiveness?" International Peacekeeping 7(3): 38-47.

[12] Malan, Mark. 1996. 'Surveying The Middle Ground: Conceptual Issues and Peace-Keeping in Southern Africa." Occasional Paper No 2 - March (Available at https:// oldsite.issafrica.org/regions/south?page $=196$ ).

[13] Mackinlay, John and Jarat Chopra. 1993. "A Draft Concept of Second Generation Multinational Operations". In Providence, RI, edited by Thomas J. Watson Jr. Institute for International Studies.

[14] Malone, David. 2004. "Conclusion". In The UN Security Council: From the Cold War to the 21st Century, edited by David Malone, 617-649. Boulder, CO: Lynne Rienner Publishers.

[15] Perito, Robert M. 2015. "UN Peacekeeping in the Sahel - Overcoming New Challenges". USIP, Special Report 365, March.

[16] Piccolino, Giulia and John Karlsrud. 2011. "Withering consent, but mutual dependency: UN peace operations and African assertiveness." Conflict, Security Development 11(4): 447-471.

[17] Pinto, Maria do Céu. 2008. As Nações Unidas e a manutenção da paz. Coimbra: Almedina.

[18] Pinto, Maria do Céu. 2016. "Consequences of ThirdGeneration Peacekeeping for the United Nations." In $\mathrm{Il}$ porto del disincato. Scritti in onore di Maria Luisa Maniscalco, edited by F. Antonelli et al. Milan: Franco Angeli.

[19] Report of the Independent Inquiry into the Actions of the United Nations during the 1994 Genocide in Rwanda, S/1999/1257, December 15, 1999.

[20] Roberts, Adam. 1994. "The Crisis in UN Peacekeeping." Survival 36(3): 93-120.

[21] Rose, Sir Michael. 1998. "Military Aspects of Peacekeeping." In UN Peacekeeping in Trouble: Lessons Learned from the Former Yugoslavia, edited by Wolfgang Biermann and Martin Vadset, 153-167. Aldershot: Ashgate. 
[22] Sloan, James. 2014. "The Evolution of the Use of Force in UN Peacekeeping." Journal of Strategic Studies 37(5): 674702.

[23] Tardy, Thierry. 2014. "The Reluctant Peacekeeper: France and the Use of Force in Peace Operations'." Journal of Strategic Studies 37(5): 770-792.

[24] Tardy, Thierry. 2007. "The UN and the Use of Force: A Marriage Against Nature." Security Dialogue 38(1): 49-70.

[25] Trauner, Florian. 2017. "The EU visa suspension mechanism." Issue 2 of the European Union Institute for Security Studies (EUISS).

[26] United Nations. 1992. "An Agenda for Peace: Preventive Diplomacy, Peacemaking and Peace-Keeping." UN Doc A/47/277-S/24111, June 17.

[27] United Nations. 2009. A New Partnership Agenda: Charting a New Horizon for UN Peacekeeping. New York: UN Department of Peacekeeping Operations and Department of Field Support.

[28] United Nations. 2008. Capstone Doctrine: UN Department of Peacekeeping Operations, Peacekeeping Operations Principles and Guidelines. New York: United Nations Secretariat.

[29] United Nations, Department of Peacekeeping Operations/Department of Field Support. 2015. "The Protection of Civilians in United Nations Peacekeeping," Ref. 2015/07 April 1. available at http: //civilianprotection.rw/wp-content/uploads/2015/05/ 2015-07-Policy-on-PoC-in-Peacekeeping-Operations.pdf.

[30] United Nations. 1995. Supplement to an Agenda for Peace: Position Paper of the Secretary- General on the Occasion of the Fiftieth Anniversary of the United Nations (UN doc. A/ 50/60-S/1995/1), January 3.

[31] United Nations General Assembly [UNGA], Report of the Secretary-General pursuant to General Assembly resolution 53/35: The fall of Srebrenica (A/54/549), November 15, 1999.

[32] United Nations General Assembly. 2012. Report of the Special Committee on Peacekeeping Operations (A/66/19), substantive session (New York, February 21 - March 16 and September 11.

[33] UNDPKO. 2008. United Nations Peacekeeping Operations: Principles and Guidelines (Capstone Doctrine), January.

[34] United Nations. 2000. Report of the Panel on United Nations Peace Operations. New York: United Nations.

[35] United Nations. 2000. Report of the Panel on United Nations Peace Operations. New York: United Nations.

[36] UN Security Council [UNGA]/ UNGeneral Assembly. 2015. The Future of United Nations Peace Operations: Implementation of the Recommendations of the High-Level Independent Panel on Peace Operations, Report of the Secretary-General. A/70/357-S/2015/682, September 2.

[37] UN Security Council. 2000. Security Council resolution 1296. S/RES/1296. April 19.

[38] UN Security Council. 2006. Security Council resolution 1674 of 2006. S/RES/1674 (2006). April 28.

[39] UN Security Council. 2007. Security Council resolution 1769. S/RES/1769 (2007). July 31.

[40] United Nations Security Council. 2000. Security Council resolution 1296, S/RES/1296 (2000). April 19.

[41] United Nations. 2004. A More Secure World: Our Shared Responsibility. Report of the Secretary-General's Highlevel Panel on Threats, Challenges, and Change (http: //www.un.org/secureworld/)

[42] Urquhart, Sir Brian. 1991. "Who Can Stop Civil Wars?" The New York Times, December 29.
[43] Viana, Vítor Rodrigues Viana. 2002. Segurança colectiva: A ONU e as operações de apoio à paz. Lisbon: IDN/Edições Cosmos.

[44] Weiss, Thomas. 1995. "Overcoming the Somalia Syndrome 'Operation Rekindle Hope'?" Global Governance 1(2): 17476.

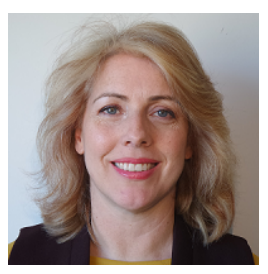

Maria do Céu Pinto Arena Associate Professor with Aggregation of the Department of International Relations and Public Administration of University of Minho. Researcher of the Research Center in Political Science (CICP). Holds a Ph.D. from the Center for Middle Eastern and Islamic Studies, Faculty of Social Sciences of University of Durham, UK. Her research areas are focused on World and Middle East Studies and International Organizations, including a UN and other regional institutions. 